\title{
Angiotensin converting enzyme inhibiting therapy is associated with lower vitreous vascular endothelial growth factor concentrations in patients with proliferative diabetic retinopathy
}

\author{
I. M.Hogeboom van Buggenum ${ }^{1}$, B.C.P.Polak ${ }^{1}$, J.W.M. Reichert-Thoen ${ }^{1}$, W.A.E.J. de Vries-Knoppert ${ }^{1}$, V.W.M. \\ van Hinsbergh ${ }^{2}$, G.J. Tangelder ${ }^{2}$ \\ ${ }^{1}$ Department of Ophthalmology, Institute for Cardiovascular Research (ICaR-VU), VU University Medical Center, Amsterdam, \\ The Netherlands \\ ${ }^{2}$ Department of Physiology, Institute for Cardiovascular Research (ICaR-VU), VU University Medical Center, Amsterdam, \\ Gaubius Laboratory TNO-PG, Leiden, The Netherlands
}

\section{Abstract}

Aims/hypothesis. Vascular endothelial growth factor (VEGF) is thought to be instrumental in the progression of diabetic retinopathy. Indications exist that the renin-angiotensin system is involved in VEGF overexpression. We assessed the vitreous VEGF concentrations in patients and related them to anti-hypertensive treatment, with special interest in the use of ACE-inhibitors.

Methods. Samples of vitreous fluid (10-80 $\mu \mathrm{l})$ were obtained from 39 patients both with Type I (insulindependent) and Type II (non-insulin-dependent) diabetes mellitus and 11 non-diabetic patients undergoing intra-ocular surgery. The VEGF-A concentrations were assessed by immunoassay.

Results. Control patients and patients without proliferative diabetic retinopathy $(n=8)$ had low and comparable VEGF concentrations (medians $<50 \mathrm{pg} / \mathrm{ml}$ ). In contrast, patients with proliferative diabetic retinopathy $(n=31)$ had high vitreous VEGF concentrations (median $1134 \mathrm{pg} / \mathrm{ml}$ ), which showed a negative correlation with the use of ACE inhibiting medication (Spearman rank-R $=-0.54 ; p=0.002, n=13$ ). Diastolic and systolic blood pressure did not differ significantly between the two subgroups with proliferative diabetic retinopathy, i.e. those patients receiving ACE-inhibition (medians 88/160 mm Hg, respectively) and the others (90/160). For the mostly used ACE-inhibitor in the proliferative diabetic retinopathy group, i.e. enalapril $(n=8)$, a linear doseeffect relation was observed $\left(-20 \pm 4 \mathrm{pg} \cdot \mathrm{ml}^{-1}\right.$. $\mathrm{mg}^{-1} \cdot \mathrm{day}^{-1} ; p=0.024$; coefficient $\left.\pm \mathrm{SEM}\right)$.

Conclusion/interpretation. Treatment with ACE-inhibitors attenuates retinal overexpression of VEGF$\mathrm{A}$ in patients with proliferative diabetic retinopathy, probably by interference with a local effect of angiotensin II. [Diabetologia (2002) 45: 203-209]

Keywords Angiotensin-converting enzyme inhibitors, vascular endothelial growth factor, diabetic retinopathy, diabetes mellitus, enalapril, antihypertensive agents, patients.
Vascular endothelial growth factor (VEGF) is an angiogenic and permeability-enhancing glycoprotein that predominantly acts on endothelial cells. Several

Received: 25 June 2001 and in revised form: 25 October 2001

Corresponding author: B.C.P. Polak, M.D., PhD, Department of Ophthalmology, Institute for Cardiovascular Research (ICaR-VU), VU University Medical Center, PO Box 7057, 1007 MB Amsterdam, The Netherlands, e-mail: bcp.polak@ vumc.nl

Abbreviations: HIF-1 $\alpha$, Hypoxia-inducible factor-1 $\alpha$; PDR, proliferative diabetic retinopathy; VEGF, vascular endothelial growth factor studies have indicated an increased retinal VEGF production in patients with proliferative diabetic retinopathy [1-3]. A hallmark of this disease is neovascularization [4]. Among the retinal cells able to produce VEGF are Müller glial cells, pigment epithelial cells, vascular smooth muscle cells and pericytes [5].

Factors implicated in the pathogenesis of diabetic retinopathy that have been shown to increase retinal VEGF expression include glucose [6], advanced glycation end products [7], protein kinase $\mathrm{C}$ activation $[8,9]$ and angiotensin II [10]. This latter substance is generated from blood-born angiotensinogen by the 
Table 1. Patient characteristics. Represented are median values and ranges, with outliers mentioned separately

\begin{tabular}{lccc}
\hline & Controls $(n=11)$ & $\begin{array}{l}\text { Diabetic patients without } \\
\text { proliferative } \\
\text { retinopathy }(n=8)\end{array}$ & $\begin{array}{l}\text { Diabetic patients with } \\
\text { proliferative } \\
\text { retinopathy }(n=31)\end{array}$ \\
\hline$n$ (male/female) & & $8(2 / 6)$ & $31(10 / 21)$ \\
Age (years) & $11(4 / 7)$ & $67(59-74)$ & $58(26-77)$ \\
Hypertension (\% of patients) & $71(19-91)$ & $25 \%$ & $62,5 \%$ \\
Systolic blood pressure (mm Hg) & $18 \%$ & $150(110-165)$ & $160(100-200)$ \\
Diastolic blood pressure (mm Hg) & $140(110-170)$ & $90(70-95)$ & $90(70-105)$ \\
Body mass index & $85(70-110)$ & $29,4(22-36,7)$ & $27,7(19,8-38,1)$ \\
Intraocular pressure (mm Hg) & $26,1(20,2-29,6)$ & $19(12-21 ; 38)$ & $19(12-22 ; 29)$ \\
\hline
\end{tabular}

Table 2. Diabetic parameters. Represented are median values and ranges

\begin{tabular}{lll}
\hline & $\begin{array}{l}\text { Diabetic pa- } \\
\text { tients without } \\
\text { proliferative } \\
\text { retinopathy } \\
(n=8)\end{array}$ & $\begin{array}{l}\text { Diabetic pa- } \\
\text { tients with pro- } \\
\text { liferative retin- } \\
\text { opathy }(n=31)\end{array}$ \\
\hline $\begin{array}{l}\text { Diabetes type (early/late onset) } \\
\text { Age of onset (years) }\end{array}$ & $0 / 8$ & $8 / 23$ \\
$\begin{array}{l}\text { Diabetes duration (years) } \\
\begin{array}{l}\text { Diabetes medication } \\
\text { (tablets/insulin) }\end{array}\end{array}$ & $58,5(43-73)$ & $42(6-75)$ \\
\hline
\end{tabular}

subsequent actions of renin and angiotensin converting enzyme (ACE). The renin angiotensin system is activated in the setting of chronic hyperglycaemia [11]. Components of this system have been found in the retina [12], and increased concentrations of prorenin, renin and angiotensin II have been reported in vitreous fluid of patients with proliferative diabetic retinopathy $[13,14]$. Diabetic children with increased plasma concentrations of prorenin are at a high risk for the development of retinopathy [15]. In vitro studies indicate that angiotensin II stimulates the secretion of VEGF by vascular smooth muscle cells $[10,16,17]$, mesangial cells $[18,19]$ and pericytes [20]. The induction of VEGF by angiotensin II requires hyperglycaemic [16] or oxidative conditions [17], which are states that accompany diabetes. In streptozotocin-induced diabetic rats it has been shown that ACE-inhibition reduces the increased concentrations of $V E G F m R N A$ in the retina [21].

If the renin-angiotensin system also plays a role in the VEGF overexpression that accompanies proliferative diabetic retinopathy in humans, one would expect that the VEGF accumulation in the ocular fluid becomes reduced upon medicinal intervention of angiotensin II-mediated processes. Therefore, we have measured VEGF concentrations in the vitreous fluid of diabetic patients with and without proliferative retinopathy and of non-diabetic control subjects and related the obtained values to the medication used. Because the majority of the patients with proliferative retinopathy also had hypertension, we focussed on anti-hypertensive treatment with a special interest in the use of ACE-inhibitors.

\section{Subjects and methods}

A total of 50 samples of vitreous fluid were obtained for crosssectional study during 1996 to 1999 from diabetic and non-diabetic patients undergoing intraocular surgery in the university hospital of the Vrije Universiteit medical center (VUmc), Amsterdam, the Netherlands. The study protocol had been approved by the local medical ethics committee. All patients signed a written informed consent before the study. Patients with other vascular diseases of the eye, e.g. vascular occlusion, were excluded.

Patient characteristics in the control group, the diabetic patients with and those without proliferative diabetic retinopathy are shown in Table 1 . The second group contains both diabetic patients without retinopathy $(n=4)$ and diabetic patients in whom retinopathy had not yet progressed to the proliferative stage $(n=4)$; pooling of these small subgroups was justified because their vitreous VEGF concentrations did not differ significantly. Hypertension was defined as a systolic blood pressure equal to or exceeding $160 \mathrm{mmHg}$ or a diastolic blood pressure of $95 \mathrm{mmHg}$ or higher, and/or as receiving antihypertensive drug treatment [22]. The diabetic characteristics of the groups with and without proliferative retinopathy are shown in Table 2. Diabetic retinopathy was assessed by fundoscopy and fundus photography according to international standards [23].

At the beginning of surgery (see below) undiluted samples of vitreous fluid (volumes 10-80 $\mu \mathrm{l}$ ) were taken in sterile tubes, cooled immediately in a refrigerator inside the operation complex and frozen to $-80^{\circ} \mathrm{C}$ within a few hours.

In non-diabetic control patients the indications for surgery were: macular pucker $(n=6)$, intraocular lens luxation $(n=1)$, dropped nucleus $(n=1)$, secondary implant $(n=1)$ and 'fresh' retinal detachment $(n=2)$. Diabetic patients without proliferative retinopathy were operated because of dropped nucleus $(n=3)$, intraocular lens luxation $(n=1)$, macular hole $(n=2)$ and macular pucker $(n=2)$. The indications for vitrectomy in patients with proliferative diabetic retinopathy were: persistent vitreous haemorrhage $(n=11)$, subhyaloid bleeding in the macular area $(n=5)$, traction retinal detachment $(n=12)$ and progressive fibrovascular proliferation $(n=3)$.

Assessment of the VEGF concentration was done blinded with a Quantikine human VEGF immunoassay purchased from $\mathrm{R}$ and $\mathrm{D}$ systems (Abingdon, UK). This assay detects soluble isoforms of VEGF-A (VEGF-A (V21 $_{12}$ and VEGF-A ${ }_{165}$ ) with high efficacy. The detection limit of the assay for VEGF in ocular fluid is $20 \mathrm{pg} / \mathrm{ml}$; the assay is linear up to $1000 \mathrm{pg} / \mathrm{ml}$. The ocular fluid of a patient with proliferative diabetic retinopathy 
was assayed in serial dilutions, which gave identical values. According to the supplier the intra-assay variation was $5.4 \%$ and the interassay variation $7.3 \%$.

Statistical analyses were carried out using SPSS version 9.0 (Chicago, Ill., USA). First non-parametric statistics were used: Spearman rank correlation testing (coefficient Rs), Kruskall Wallis and Mann-Whitney U test.

Stepwise multiple linear regression was applied in a subgroup of the patients with proliferative diabetic retinopathy treated with ACE inhibiting medication, i. e. those taking enalapril. This subgroup was sufficiently large to analyse a possible relation between the dose of this ACE inhibitor and vitreous VEGF concentrations. Such analysis was warranted because co-use of medication, especially diuretics, was often present. The distribution of the y-value (VEGF) in this subgroup was not clearly different from normal (Shapiro-Wilks, $p>0.48$ ). For dichotomic parameters, like use or non-use of a type of medication, we used dummy variables $(0$ is absent, 1 is present). Parameters were one-by-one entered to optimize the adjusted $\mathrm{R}^{2}$, and were kept if their $p$ value on entering was 0.15 or smaller; thereafter $p$ values were corrected according to Bonferroni [24]. A two-tailed $p$ value of less than 0.05 was considered significant for all tests.

\section{Results}

The VEGF values measured in the vitreous fluid of the three patient groups are given in Figure 1. Nondiabetic patients and diabetic patients without proliferative diabetic retinopathy had low and comparable VEGF concentrations (medians $<50 \mathrm{pg} / \mathrm{ml}$ ). In contrast, patients with proliferative diabetic retinopathy (PDR) had values at least an order of magnitude higher (median $1134 \mathrm{pg} / \mathrm{ml}, p<0.001$ ). The VEGF concentrations in PDR-patients did not differ between those dependent on insulin (median $1134 \mathrm{pg} /$ $\mathrm{ml}$; range 143-8000) and the Type II (non-insulin-dependent) diabetic patients (median $1172 \mathrm{pg} / \mathrm{ml}$; range 20-5142).

In each diabetic group the patients with the highest vitreous VEGF concentration (Fig. 1) received acetazolamide (dose three times, $250 \mathrm{mg}$ daily) because of glaucoma: these two patients were also the 'outliers' with regard to the intraocular pressure shown in Table 1 (i. e. 38 and $29 \mathrm{mmHg}$, respectively). The other patients had intraocular pressures within the normal range; no significant correlations were observed between these pressures and the vitreous VEGF concentrations in any of these groups.

In the non-diabetic group two patients were hypertensive, one using a beta-blocker and the other a calcium antagonist; both had undetectable vitreous VEGF concentrations. In the diabetic patients without proliferative PDR, one patient used a betablocker for hypertension and another a calcium antagonist with beta-blocker for angina pectoris; they also had no detectable vitreous VEGF concentrations. A third patient in this group had diuretic treatment (triamterene) because of leg-edema (VEGF $149 \mathrm{pg} / \mathrm{ml})$.

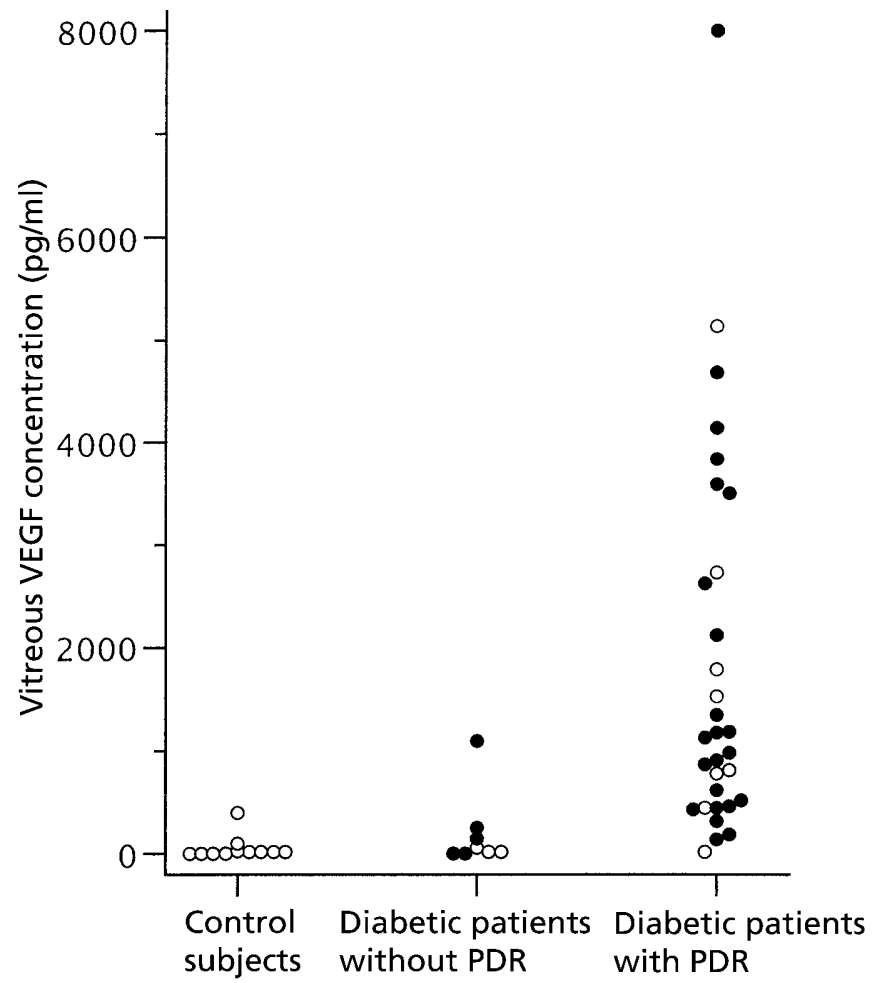

Fig. 1. Vitreous VEGF concentrations in the control group, the diabetic patients without and those with proliferative diabetic retinopathy (PDR). Diabetic patients treated with insulin are indicated by a solid symbol; the others received tablets, except one patient who became medication-free after severe weight loss (PDR with a VEGF concentration of $787 \mathrm{pg} / \mathrm{ml}$ ). Values of zero or below denote concentrations below the detection limit of $20 \mathrm{pg} / \mathrm{ml}$

$A C E$ inhibition and vitreous VEGF concentrations in proliferative diabetic retinopathy patients. The wide range of VEGF concentrations found in patients with PDR (Fig. 1) did not correlate with any of the parameters shown in Tables 1 and 2, including diagnosed hypertension ( $\mathrm{Rs}=-0.139, p=0.46)$. In contrast, a significant negative correlation was found for the use of ACE inhibiting medication $(\mathrm{Rs}=-0.542$, $p=0.002, n=13)$ and a positive correlation for the use of diuretics (Rs $=0.453, p=0.012, n=10)$. $\mathrm{HbA}_{1 \mathrm{c}}$-concentrations were known for a subgroup of 12 PDR patients (median 8.2\%; range 5.6-9.8). These $\mathrm{HbA}_{1 \mathrm{c}}$ concentrations did not correlate with the vitreous VEGF values $(\mathrm{Rs}=-0.179, p=0.58)$ and also did not differ $(p=0.7)$ between patients treated with an ACE-inhibitor $(n=6)$ or not. On the other hand, these $\mathrm{HbA}_{1 \mathrm{c}}$ concentrations correlated positively $(\mathrm{Rs}=0.59, p=0.044)$ with the duration of diabetes (Table 2).

The vitreous VEGF concentrations in patients with PDR, comparing those using ACE inhibition with the others are shown in Figure 2. The patients treated with ACE inhibitors had lower vitreous VEGF concentrations $(p=0.045)$ despite more co- 


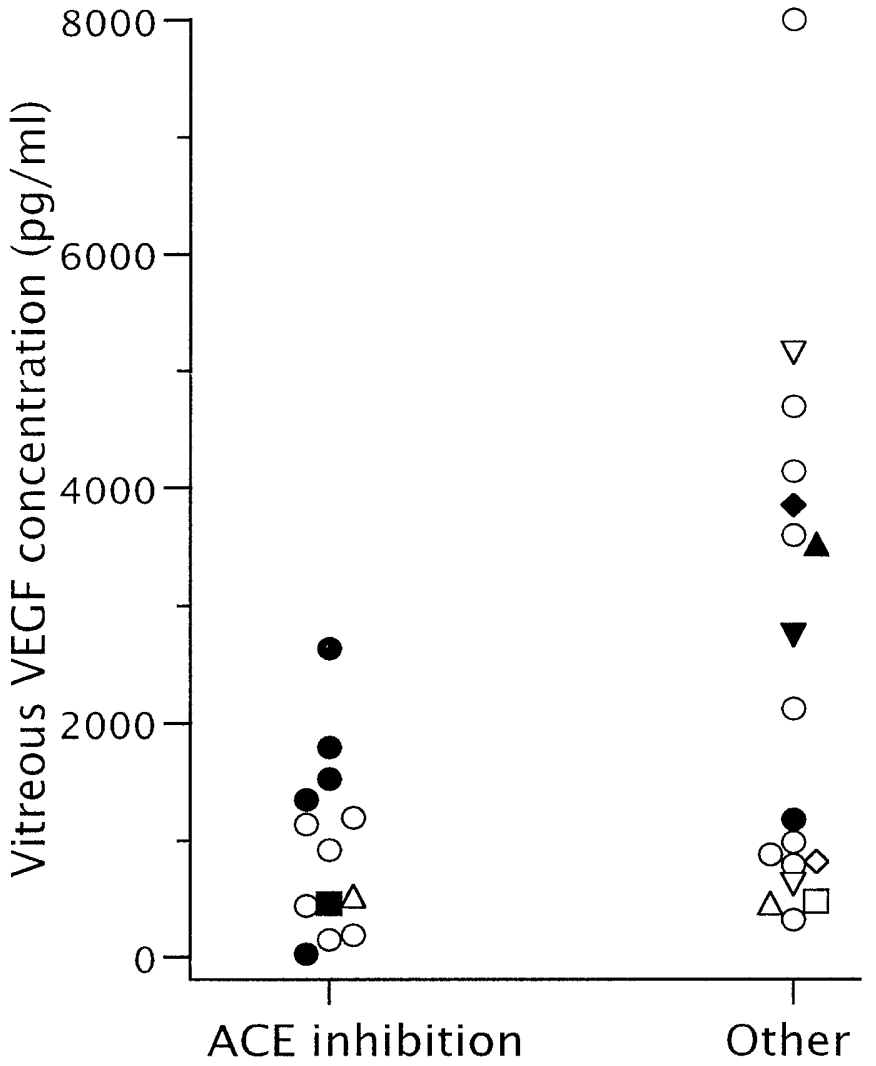

Fig. 2. Vitreous VEGF concentrations in patients with proliferative diabetic retinopathy, either treated with an ACE-inhibitor or not receiving such compounds. In both groups solid symbols represent co-use or use of a diuretic. Presence or absence of vasoactive medication is indicated by the following symbols: $\bigcirc$, ACE-inhibition (left) or no vasoactive medication (right): $\triangle$, beta-blocker; $\nabla$, calcium antagonist; $\diamond$, angiotensin II receptor blocker; $\square$, combination of beta-blocker and calcium antagonist; one such case was also present in the ACE-inhibition group (with co-use of a diuretic)

use of diuretics. The diuretics might have attenuated the ACE inhibitor effect, because of the positive correlation found between diuretics and vitreous VEGF concentrations. Diastolic and systolic blood pressure did not differ $(p>0.9)$ between the group receiving ACE inhibitors (medians $88 / 160 \mathrm{mmHg}$; ranges 70-105/100-200, respectively), and the others (90/ $160 \mathrm{mmHg}$; 80-100/130-190).

In the ACE inhibition group, 8 of the 13 patients used enalapril (daily dose 5-40 mg, median $30 \mathrm{mg}$ ), while the others used ramipril $(5 \mathrm{mg})$, fosinopril (20 mg), trandolapril (5 mg), lisinopril (20 mg), and captopril (100 mg), respectively. The relation between enalapril dose and vitreous VEGF concentration is shown (Fig.3). Four of the patients simultaneously used a diuretic, with a pronounced difference in VEGF concentrations between the two patients using a loop diuretic at a relatively high dose and those using a thiazide-derivative at a modest dose (Fig. 3). Multiple linear regression analysis with the three medications entered yielded $\mathrm{R}^{2}=0.952$ (constant \pm SEM

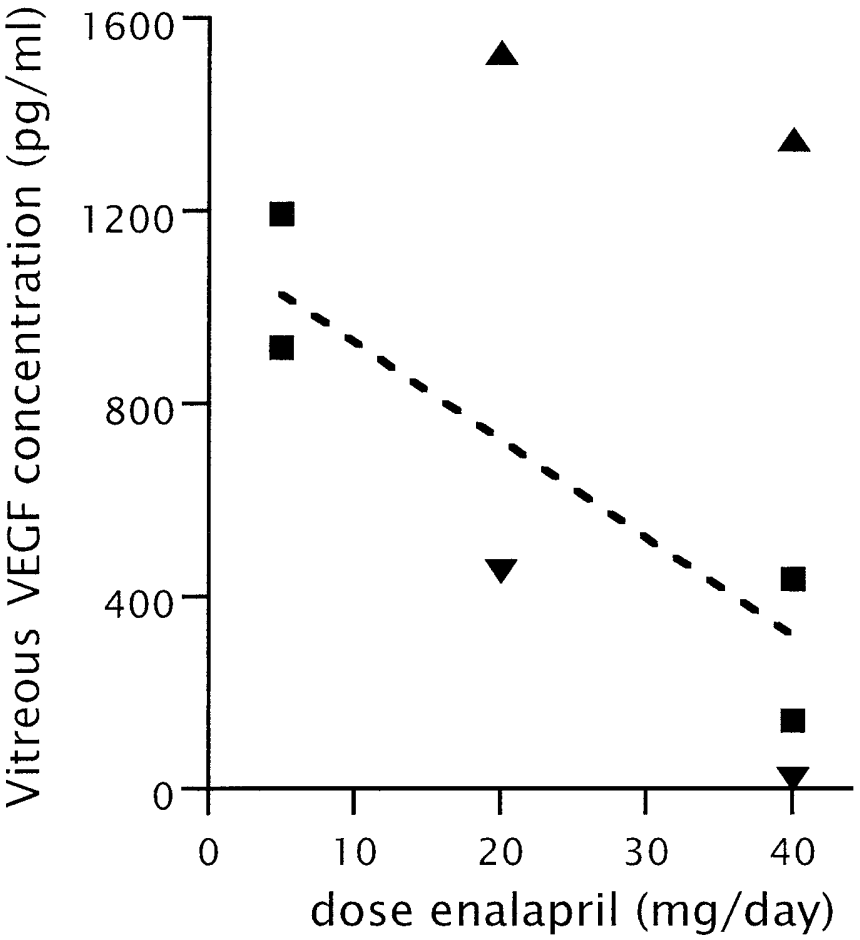

Fig.3. Relation between enalapril dose used and vitreous VEGF concentrations in patients with proliferative diabetic retinopathy. The dashed line shows the relation as indicated by the multiple regression analysis (see text). Symbols indicate use of $\boldsymbol{\square}$, enalapril only; $\boldsymbol{\Lambda}$, enalapril combined with a loop diuretic (left: furosemide $40 \mathrm{mg}$ and right: bumetanide $5 \mathrm{mg}$ ); $\boldsymbol{\nabla}$, enalapril combined with a thiazide derivative (left: hydrochloorthiazide $25 \mathrm{mg}$, and right: chloortalidon $25 \mathrm{mg}$ )

$1128 \pm 124 \mathrm{pg} / \mathrm{ml}, p=0.012)$ and a significant effect for dose of enalapril $\left(-20 \pm 4 \mathrm{pg} \cdot \mathrm{ml}^{-1} \cdot \mathrm{mg}^{-1} \cdot\right.$ day $^{-1}$; $p=0.024$ ) (Fig. 3). Entering the indicators for surgery in this analysis showed no significant influence.

\section{Discussion}

Our study shows that patients with proliferative diabetic retinopathy who are treated with an ACE inhibitor have relatively lower vitreous VEGF concentrations. Moreover, in the patients receiving enalapril, the most often prescribed ACE-inhibitor in our study, a strong negative correlation was found between vitreous VEGF concentration and the daily dose used. The VEGF concentrations found in the vitreous fluid of patients with proliferative diabetic retinopathy were generally rather high (median 1134, mean 1825 $\mathrm{pg} / \mathrm{ml} ; n=31$ ). This finding is in line with other studies, one reporting in 20 patients a median value of $1164 \mathrm{pg} / \mathrm{ml}[1]$ and another in 75 patients a mean value of $1710 \mathrm{pg} / \mathrm{ml}$ [2].

To date, there are no published investigations in humans on ACE inhibition therapy and VEGF concentrations in the eye. In rats, ACE inhibitor treat- 
ment reduced the retinal overexpression of VEGF mRNA both in streptozotocin-induced diabetes [21] and in a retinopathy of prematurity model [25]. ACE inhibitors attenuate the formation of angiotensin II and the break-down of bradykinin. Studies in vitro have shown that angiotensin II is able to stimulate the expression of VEGF in bovine retinal pericytes [20], rat heart endothelial cells [26], as well as human vascular smooth muscle $[10,16,17]$ and mesangial cells $[18,19]$. Moreover, increased concentrations of angiotensin II have been found in the vitreous fluid of patients with proliferative diabetic retinopathy $[13,14]$. Therefore, it is feasible that a reduction in retinal angiotensin II concentrations was involved in the lowering effect of ACE inhibition on the high vitreous VEGF concentrations of patients with proliferative diabetic retinopathy.

Besides inhibition of a specific local effect of angiotensin II on retinal cells, a reduction in systemic blood pressure by the ACE inhibitors could have contributed to their lowering effect on the increased vitreous VEGF concentrations. However, of the patients with proliferative diabetic retinopathy, the blood pressure of those receiving ACE inhibition was not significantly different from the others. In the patients receiving other blood pressure-lowering medication rather high VEGF values still occurred, whereas for the use of diuretics even a positive correlation was found. Both systolic and diastolic blood pressure did not correlate to the high vitreous VEGF concentrations in patients with proliferative diabetic retinopathy. These observations support the idea expressed in literature that the cardiovascular and metabolic benefits of ACE inhibitors are not merely due to their antihypertensive effect but that 'something else' explains the therapeutic mechanism [27, 28].

An intracellular signalling pathway that could mediate an angiotensin II-induced overexpression of VEGF in the retina involves hypoxia-inducible factor- $1 \alpha$ (HIF-1 $\alpha)$. In addition to hypoxia, it has been shown that this transcription factor can be increased by various agonists [17] of which angiotensin II was the most potent. The mechanism of HIF-1 $\alpha$ induction by angiotensin II depends on the production of reactive oxygen species [17]. The observation that hyperglycaemia is required to detect angiotensin II-induced expression of VEGF in cultured smooth muscle cells [16] could also be related to the formation of radicals, because of an altered cellular redox state induced by hyperglycaemia. These in vitro observations agree closely with earlier in vivo observations in rat aorta, namely that infusion of angiotensin II increases the production of superoxide anions by activation of NADPH oxidase, an effect that could be blocked completely by losartan $[29,30]$. From these data on smooth muscle cells a sequence of events is suggested that connects cellular activation by angiotensin II via NADPH oxidase activation, superoxide production and HIF-
$1 \alpha$ activation to the transcriptional activation of the $V E G F$ gene. Although such a mechanism has yet to be verified in the eye and the retina, the fact that angiotensin II also increases VEGF transcription and production in pericytes and mesangial cells points to a broader implication of the suggested mechanism.

Another factor identified in vitro that also could contribute to VEGF overexpression is cell stretch [31]. In the retina cell stretch can be caused by an increased intraocular pressure. However, our patients with proliferative diabetic retinopathy did not differ from the others regarding intraocular pressure and normal values of this parameter did not correlate with vitreous VEGF concentrations. Hence, it seems unlikely that retinal stretch has been an important determinant for the high VEGF concentrations found in patients with proliferative diabetic retinopathy. Conversely, the two glaucoma patients in our study did have exceptionally high VEGF concentrations, indicating that under conditions of increased intraocular pressure (29-38 $\mathrm{mm} \mathrm{Hg}$ ) retinal stretch could be a factor leading to increased VEGF-expression.

Beneficial effects of ACE-inhibition reducing complications of diabetes mellitus have been reported for retinopathy [32-34], neuropathy [35] and nephropathy [36-38]. A strong association between these complications is shown by epidemiological studies [35], probably based on microvascular dysfunction. In diabetic patients ACE-inhibition reduces microalbuminuria and normalizes an increased skin capillary permeability [38]. It also attenuates the increased retinal blood flow [39], which parallels the progression of nonproliferative diabetic retinopathy [40]. Beneficial effects of ACE-inhibition on diabetic microangiopathy could involve VEGF at various stages. Apart from its angiogenic and permeability enhancing effect, VEGF can increase retinal blood flow [40]. ACE-inhibitors could influence the role of VEGF in microangiopathy either by attenuating its overexpression as shown in this study for proliferative retinopathy, or by reducing the number of VEGF receptors [41], or both.

In conclusion, we found that the high vitreous VEGF concentrations present in patients with proliferative diabetic retinopathy are lower in those patients treated with an ACE inhibitor. Moreover, a clear and linear dose-effect relation was observed for the mostly used ACE inhibitor, enalapril. Differences in blood pressure did not seem to be a major determining factor. Hence, it is suggested that interference with a retinal effect of one or more of the ACE-related agonists, most likely angiotensin II, is involved in the observed association between ACE inhibiting therapy and lower vitreous VEGF concentrations in patients with proliferative diabetic retinopathy.

Acknowledgements. V.W. M. van Hinsbergh was supported by a grant from the USF of the Vrije Universiteit. 


\section{References}

1. Adamis AP, Miller JW, Bernal MT el al. (1994) Increased vascular endothelial growth factor levels in the vitreous of eyes with proliferative diabetic retinopathy. Am J Ophthalmol 118: 445-450

2. Aiello LP, Avery RL, Arrigg PG et al. (1994) Vascular endothelial growth factor in ocular fluid of patients with diabetic retinopathy and other retinal disorders. $\mathrm{N}$ Eng $\mathrm{J}$ Med 331: 1480-1487

3. Amin RH, Frank RN, Kennedy A, Eliott D, Puklin JE, Abrams GW (1997) Vascular endothelial growth factor is present in glial cells of the retina and optic nerve of human subjects with nonproliferative diabetic retinopathy. Invest Ophthalmol Vis Sci 38: 36-47

4. D'Amore PA (1994) Mechanisms of retinal and choroidal neovascularization. Invest Ophthalmol Vis Sci 35: 3974-3979

5. Yoshida A, Yoshida S, Ishibashi T, Inomata H (1999) Intraocular neovascularization. Histol Histopathol 14: 1287-1294

6. Williams B (1997) Factors regulating the expression of vascular permeability/vascular endothelial growth factor by human vascular tissues. Diabetologia 40: S118-S120

7. Lu M, Kuroki M, Amano S et al. (1998) Advanced glycation end products increase retinal vascular endothelial growth factor expression. J Clin Invest 101: 12191224

8. Williams B, Gallacher B, Patel H, Orme C (1997) Glucoseinduced protein kinase $\mathrm{C}$ activation regulates vascular permeability factor mRNA expression and peptide production by human vascular smooth muscle cells in vitro. Diabetes 46: 1497-1503

9. Aiello LP, Bursell SE, Clermont A et al. (1997) Vascular endothelial growth factor-induced retinal permeability is mediated by protein kinase $\mathrm{C}$ in vivo and supressed by an orally effective $\beta$-isoform-selective inhibitor. Diabetes 46: 1473-1480

10. Williams B, Baker AQ, Gallacher B, Lodwick D (1995) Angiotensin II increases vascular permeability factor gene expression by human vascular smooth muscle cells. Hypertension 25: 913-917

11. Anderson S, Jung FF, Ingelfinger JR (1993) Renal reninangiotensin system in diabetes: functional, immunohistochemical, and molecular biological correlations. Am J Physiol 265: F477-F486

12. Berka JL, Stubbs AJ, Wang DZ et al. (1995) Renin-containing Muller cells of the retina display endocrine features. Invest Ophthalmol Vis Sci 36: 1450-1458

13. Danser AH, van den Dorpel MA, Deinum J et al. (1989) Renin, prorenin, and immunoreactive renin in vitreous fluid from eyes with and without diabetic retinopathy. J Clin Endocrinol Metab 68: 160-167

14. Danser AH, Derkx FH, Admiraal PJ, Deinum J, De Jong PT, Schalekamp MA (1994) Angiotensin Levels in the Eye. Invest Ophthalmol Vis Sci 35: 1008-1018

15. Wilson DM, Luetscher JA (1990) Plasma prorenin activity and complications in children with insulin-dependent diabetes melitus. N Eng J Med 323: 1101-1106

16. Natarajan R, Bai W, Lanting L, Gonzales N, Nadler J (1997) Effects of high glucose on vascular endothelial growth factor expression in vascular smooth muscle cells. Am J Physiol 273: H2224-H2231

17. Richard DE, Berra E, Pouysségur J (2000) Nonhypoxic pathway mediates the induction of hypoxia-inducible factor 1 alpha in vascular smooth muscle cells. J Biol Chem 275: 26765-26771
18. Gruden G, Thomas S, Burt D et al. (1999) Interaction of angiotensin II and mechanical stretch on vascular endothelial growth factor production by human mesangial cells. J Am Soc Nephrol 10: 730-737

19. Pupilli C, Lasagni L, Romagnani P et al. (1999) Angiotensin II stimulates the synthesis and secretion of vascular permeability factor/vascular endothelial growth factor in human mesangial cells. J Am Soc Nephrol 10: 245-255

20. Otani A, Takagi H, Oh H et al. (2000) Angiotensin II-stimulated vascular growth factor expression in bovine retinal pericytes. Invest Ophthalmol Vis Sci 41: 1192-1199

21. Gilbert RE, Kelly DJ, Cox AJ et al. (2000) Angiotensin converting enzyme inhibition reduces retinal overexpression of vascular endothelial growth factor and hyperpermeability in experimental diabetes. Diabetologia 43: 1360-1367

22. World Health Organization (1978) Arterial hypertension. Technical Report Series No 628, World Health Organization, Geneva

23. Aldington SJ, Kohner EM, Meuer S, Klein R, Sjolie AK (1995) Methodology for retinal photography and assessment of diabetic retinopathy: the EURODIAB IDDM Complications Study. Diabetologia 38: 437-444

24. Afifi AA, Clark V (1996) Computer-Aided multivariate analysis, 3rd edi Chapman Hall texts in statistical science series, London p176

25. Moravski CJ, Kelly DJ, Cooper ME et al. (2000) Retinal neovascularization is prevented by blockade of the reninangiotensin system. Hypertension 36: 1099-1104

26. Chua CC, Hamdy RC, Chua BHL (1998) Upregulation of vascular endothelial growth factor by angiotensin II in rat heart endothelial cells. Biochim Biophys Acta 1401:187-194

27. Pahor M, Psaty BM, Alderman MH, Applegate WB, Williamson JD, Furberg CD (2000) Therapeutic benefits of ACE inhibitors and other antihypertensive drugs in patients with type 2 diabetes. Diabetes Care 23: 888-892

28. Gerstein HC (2000) Cardiovascular and metabolic benefits of ACE inhibition : moving beyond blood pressure reduction. Diabetes Care 23: 882-883

29. Rajagopalan S, Kurz S, Munzel T et al. (1996) Angiotensin II-mediated hypertension in the rat increases vascular superoxide production via membrane NADH/NADPH oxidase activation. Contribution to alterations of vasomotor tone. J Clin Invest 97: 1916-1923

30. Laursen JB, Rajagopalan S, Galis Z, Tarpey M, Freeman BA, Harrison DG (1997) Role of superoxide in angiotensin II-induced but not catecholamine-induced hypertension Circulation 95: 588-593

31. Gruden G, Thomas S, Burt D et al. (1997) Mechanical stretch induces vascular permeability factor in human mesangial cells: mechanisms of signal transduction. Proc Natl Acad Sci USA 94: 12112-12116

32. Chaturvedi N, Sjolie AK, Stephenson JM et al. (1998) Effect of lisinopril on progression of retinopathy in normotensive people with type 1 diabetes. Lancet 351: 28-31

33. Chase HP, Garg SK, Harris S, Hoops S, Jackson WE, Holmes DL (1993) Angiotensin converting enzyme inhibitor treatment for young normotensive diabetic subjects: a two-year trial. Ann Ophthalmol 25: 284-289

34. Larsen M, Hommel E, Parving HH, Lund-Andersen $\mathrm{H}$ (1990) Protective effect of captopril on the blood retina barrier in normotensive insulin-dependent diabetic patients with nephropathy and background retinopathy. Graefes Arch Clin Exp Ophthalmol 228: 505-509

35. Malik RA (2000) Can diabetic neuropathy be prevented by angiotensin converting enzyme inhibitors? Ann Med 32: 1-5 
36. Cha DR, Kim NH, Yoon JW et al. (2000) Role of vascular endothelial growth factor in diabetic nephropathy. Kidney Int 58 [Suppl 77]: S104-S112

37. Chan JC, Ko GT, Leung DH et al. (2000) Long-term effects of angiotensin-converting enzyme inhibition and metabolic control in hypertensive type 2 diabetic patients. Kidney Int 57: 590-600

38. Oomen PH, Jager J, Hoogenberg K, Dullaart RP, Reitsma WD, Smit AJ (1999) Capillary permeability is increased in normo- and microalbuminuric type 1 diabetic patients: amelioration by ACE-inhibition. Eur J Clin Invest 29: 1035-1040

39. Patel V, Rassam SM, Chen HC, Jones M, Kohner EM (1998) Effect of angiotensin-converting enzyme inhibition with perindopril and betablockade with atenolol on retinal blood flow in hypertensive diabetic subjects. Metabolism 47 [Suppl 1]: 28-33

40. Clermont AC, Aiello LP, Mori F, Aiello LM, Bursell SE (1997) Vascular endothelial growth factor and severity of nonproliferative diabetic retinopathy mediate retinal hemodynamics in vivo : a potential role for vascular endothelial growth factor in the progression of nonproliferative diabetic retinopathy. Am J Ophthalmol 124: 433-446

41. Otani A, Takagi H, Suzuma K, Honda Y (1998) Angiotensin II potentiates vascular endothelial growth factor-induced angiogenetic activity in retinal microcapillary endothelial cells. Circ Res 82: 619-628 